\title{
HUBUNGAN KARATERISTIK IBU HAMIL DENGAN PENGETAHUAN TENTANG IMMUNISASI TT 2 + DI DESA PASARKEONG KECAMATAN CIBADAK KABUPATEN LEBAK TAHUN 2015
}

\author{
*Suhartini, *Ahmad
}

\begin{abstract}
Abstrak
Tetanus di 28 hari pertama kehidupan (Tetanus Neonatorum) telah lama diakui sebagai penyebab utama kematian neonatal. Upaya pencegahannya adalah melaui immunisasi TT. Data Dinkes Lebak 2013 Cakupan TT 2+ di puskesmas Cibadak baru mencapai $66,5 \%$, cakupan ini lebih rendah dari target yang ingin dicapai yaitu $80 \%$. Pada tahun 2013 di puskesmas Cibadak masih ditemukan 1 kasus TN berasal dari desa Pasir keong. Hasil penelitian terdahulu Mislianti dkk (2012) menyatakan bahwa, responden dengan pengetahuan rendah mempunyai resiko 2,497 kali lebih besar tidak melakukan imunisasi TT jika dibandingkan dengan responden yang berpengetahuan tinggi. Dari data inilah penulis tertarik untuk melihat apakah ada hubungan antara karatestik ibu dengan pengetahuan tentang immunisasi TT $2+$.

Metodelogi penelitian ini menggunakan desain Cross sectional. populasi penelitian ini adalah seluruh ibu hamil yang terdata di desa pasar keong wilayah kerja puskesmas Cibadak berjumlah 67 orang. Sampel penelitian setelah dipilih dengan menggunakan kriteria insklusi dan ekslusi didapatkan sampel berjumlah 55 orang responden, tehnik sampling menggunakan Acidental sampling. Pengumpulan data penelitian dengan menggunakan kuesioner. Penelitian ini dilaksanakan sejak pertengahan Mei s/d Juli 2015.

Hasil penelitian menunjukan bahwa sebagian besar ibu hamil berpengetahuan kurang $(67,3 \%)$, sebagian besar ibu berusia $\leq 30$ tahun $(85 \%)$, berpendidikan $\leq$ SLTP kebawah $(61,8 \%)$ sebagian besar ibu tidak bekerja $(83,6 \%)$, paritas $\leq 1(63,6 \%)$, Ibu yang tidak/belun mendapatkan TT $2+(63,6 \%)$. Ada hubungan antara pendidikan ibu dengan pengetahuan tentang immunisasi TT (OR 9,4), ada hubungan antara pekerjaan ibu dengan pengetahuan tentang immunisasi TT $2+(\mathrm{OR} 6)$, ada hubungan keterpaparan informasi dengan pengetahuan ibu tentang immunisasi TT 2+ (OR 12,6\%), Tidak ada hubungan antara usia, paritas, status immunisai TT $2+$ ibu hamil

Dari hasil analisis hubungan karateristik ibu dengan pengetahuan tentang immunisai TT 2+ disimpulkan ada hubungan bermakna antara pendidikan ibu, pekerjaan ibu dan keterpaparan informasi dengan pengetahuan ibu hamil tentang TT $2+$. Disarankan agar dalam memberikan informasi tentang immunisasi TT 2 + kepada Ibu hamil agar memperhatikan karateristik ibu meliputi; pendidikan, pekerjaan ibu dan media penyampaian informasi dalam upaya mempromosikan pentingnya immunisasi TT 2+ pada ibu hamil. Koordinasi lintas program terkait immunisasi TT $2+$ di berbagai level perlu ditingkatkan.
\end{abstract}

Kata Kunci : Pengetahuan tentang Immunisasi TT $2+$, Karateristik Ibu hamil, Cross Sectional *Poltekkes Kemenkes Banten 


\section{Pendahuluan}

Tetanus di 28 hari pertama kehidupan (tetanus neonatorum) telah lama diakui sebagai penyebab utama kematian neonatal. WHO menyatakan bahwa, pada 1980-an, lebih dari 1 juta kematian setiap tahun adalah disebabkan tetanus, dengan estimasi 787.000 kematian pada tahun 1988 dari tetanus neonatal.

Pada tahun 1989, komunitas kesehatan masyarakat di seluruh dunia membuat komitmen untuk penghapusan tetanus neonatal (Didefinisikan sebagai kurang dari satu kasus tetanus neonatal per 1000 live births di semua kabupaten) pada tahun 1995. Sejak 1989, WHO memang mentargetkan eliminasi tetanus neonatorum. Sebanyak 104 dari 161 negara berkembang telah mencapai keberhasilan itu. Tapi, karena tetanus neonatorum masih merupakan persoalan signifikan di 57 negara berkembang lain, UNICEF, WHO dan UNFPA pada Desember 1999 setuju mengulur eliminasi hingga 2005. Target eliminasi tetanus neonatorum adalah satu kasus per seribu kelahiran di masing-masing wilayah dari setiap Negara.

Kematian ibu dan Bayi sangat mempengaruhi perkembangan dan pertumbuhan bangsa di masa mendatang, oleh karena itu ibu mempunyai peran penting untuk mewujudkan keluarga yang bahagia dan sejahtera. Namun sampai saat ini masih ada ibu hamil yang kurang memperhatikan faktor -faktor yang dapat mempengaruhi pertumbuhan dan perkembangan janin diantaranya adalah masih ditemukan ibu hamil yang belum mengikuti program immunisasi TT $2+$ yang seharusnya di dapatkan lima kali selama masa usia subur, sehingga pada saat hamil ibu dan janin sudah terlindungi dengan baik.

Salah satu faktor penyebab ketidakpedulian akan immunisasi TT dari beberapa penelitian terdahulu diketahui bahwa faktor pengetahuan ibu menjadi salah satu penyebab ibu tidak memahami pentingnya immunisasi TT. Hasil penelitian Mislianti dkk (2012) menyatakan bahwa, responden dengan pengetahuan rendah mempunyai resiko 2,497 kali lebih besar tidak melakukan imunisasi TT jika dibandingkan dengan responden yang berpengetahuan tinggi.

Dari data yang ada di dinas kesehatan kabupaten Lebak diketahui bahwa cakupan immunisasi TT 2+ (TT 5 Dosis) kabupaten Lebak tahun 2013 baru mencapai 59.8\%, dan untuk wilayah kerja puskesmas cibadak cakupan TT 2+ baru mencapai 66,5\%, cakupan ini lebih baik dari cakupan kabupaten, namun lebih rendah dari target yang ingin 
dicapai yaitu $80 \%$. Di wilayah puskesmas kecamatan cibadak masih ditemukan kasus TN dalam 2 tahun terakhir sebanyak 1kasus pada tahun 2012 dan 1 kasus pada tahun 2013. Kasus yang ditemukan tahun 2013 adalah kasus yang berasal dari desa pasar keong.

Berdasarkan data-data yang ada penulis ingin melihat apakah ada hubungan antara karateristik ibu dengan pengetahuan tentang immunisasi TT $2+$ ibu hamil di desa Pasar keong wilayah kerja Puskesmas Cibadak kabupaten Lebak Banten 2015

\section{Metode Penelitian}

Desain penelitian ini adalah Desain Cross sectional merupakan rancangan penelitian dengan melakukan pengukuran/ pengamatan pada saat bersamaan (sekali waktu) antara faktor risiko/paparan dengan penyakit.

Instrumen pengumpulan data dengan menggunakan kuesioner yang telah disediakan sebelumnya, sesuai dengan variabel yang akan diteliti ( Kuesioner Terlampir)

Pada penelitian ini populasinya seluruh ibu hamil yang terdata di des desa Pasar Keong sebanyak 67 orang ibu hamil. Sedangkan sampel sama dengan populasi
Tehnik sampling dengan Accidental sampling

\section{Hasil}

\section{Analisis Univariat}

Tabel 1

Distribusi Frekuensi ibu hamil berdasarkan pengetahuan tentang Immunisasi TT 2+ di desa Pasar Keong kecamatan Cibadak tahun 2015

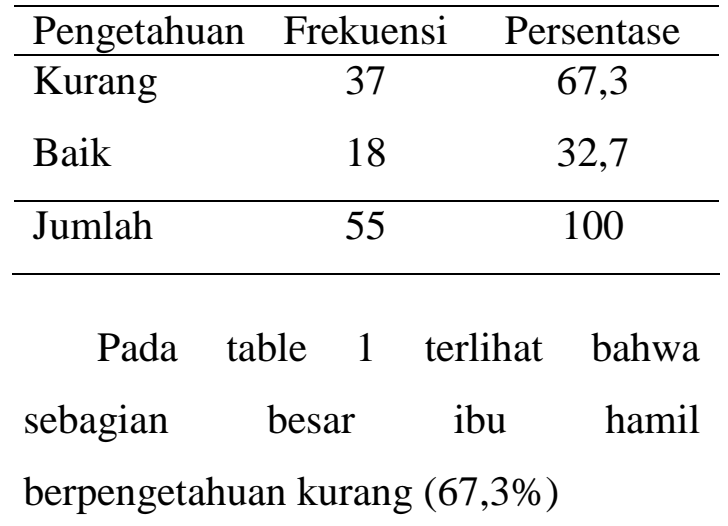

Tabel 2

Distribusi Frekuensi Ibu hamil berdasarkan Usia Di di desa Pasar Keong kecamatan Cibadak tahun 2015

\begin{tabular}{lcc}
\hline $\begin{array}{l}\text { Kelompok } \\
\text { Umur }\end{array}$ & Jumlah & Persentase \\
\hline$\leq 30$ tahun & 47 & 85,5 \\
$>30$ tahun & 8 & 14,5 \\
\hline Jumlah & 55 & 100 \\
\hline
\end{tabular}

Pada tabel 2 terlihat bahwa sebagian besar Ibu hamil berusia $\leq 30$ tahun

$(85,5 \%)$ 
Tabel 3

Distribusi Frekuensi ibu hamil berdasarkan pendidikan ibu Di desa Pasar Keong kecamatan Cibadak tahun 2015

\begin{tabular}{lcc}
\hline Tingkat & Frekuensi & $\%$ \\
Pendidikan & & \\
\hline$<$ SLTP & 34 & 61,8 \\
$>$ SLTP & 21 & 38,2 \\
\hline Jumlah & 55 & 100 \\
\hline
\end{tabular}

Pada tabel 3 terlihat bahwa lebih dari separuh Ibu hamil berpendidikan $\leq$ SLTP $(61,8 \%)$

Tabel 4

Distribusi Frekuensi Ibu hamil berdasarkan Pekerjaan di desa Pasar Keong Kecamatan Cibadak tahun 2015

\begin{tabular}{lcc}
\hline Pekerjaan & Frekuensi & $\%$ \\
\hline $\begin{array}{l}\text { Tidak } \\
\text { bekerja }\end{array}$ & 46 & 83,6 \\
Bekerja & 9 & 16,4 \\
\hline Jumlah & 55 & 100 \\
\hline
\end{tabular}

Pada tabel 4 terlihat bahwa, sebagian besar Ibu hamil tidak bekerja $(83,6 \%)$

Tabel 5

Distribusi frekuensi Ibu hamil berdasarkan paritas di Pasar Keong kecamatan Cibadak tahun 2015

\begin{tabular}{lcc}
\hline $\begin{array}{l}\text { Jumlah } \\
\text { Kelahiran }\end{array}$ & Frekuensi & $\%$ \\
\hline$\leq$ Primi & 35 & 63,6 \\
\hline$>$ Multi & 20 & 36,4 \\
\hline Jumlah & 55 & 100 \\
\hline
\end{tabular}

Pada tabel 5 terlihat bahwa lebih dari separuh ibu hamil dengan mempunyai anak $\leq 1(63,6 \%)$

Tabel 6

Distribusi frekuensi Ibu hamil berdasarkan status immunisasi TT di desa Pasar Keong kecamatan Cibadak tahun 2015

\begin{tabular}{lcc}
\hline Status & Frekuensi & $\%$ \\
Immunisasi TT & & 63,6 \\
\hline $\begin{array}{l}\text { Tidak/belum } \\
\text { Immunisasi } \\
\text { Immunisasi }\end{array}$ & 35 & 36,4 \\
\hline Jumlah & 20 & 100 \\
\hline
\end{tabular}

Pada tabel 6 terlihat bahwa, lebih dari separuh $(63,6 \%)$ Ibu hamil di desa Pasar Keong belum melaksanakan Immunisasi TT

Tabel 7

Distribusi frekuensi Ibu hamil berdasarkan keterpaparan informasi tentang immunisasi TT 2+ di desa Pasar Keong kecamatan Cibadak tahun 2015

\begin{tabular}{lcc}
\hline $\begin{array}{l}\text { Keterpaparan } \\
\text { Informasi }\end{array}$ & Frekuensi & $\%$ \\
\hline $\begin{array}{l}\text { Tidak/belum } \\
\text { pernah }\end{array}$ & 35 & 63,6 \\
Bekerja & 20 & 36,4 \\
\hline Jumlah & 55 & 100 \\
\hline
\end{tabular}

Pada tabel 7 terlihat bahwa, sebagian besar Ibu hamil (60\%) tidak terpapar informasi tentang immunisasi TT $2+$ 


\section{Analisis Bivariat}

1. Hubungan usia ibu dengan pengetahuan tentang immunisasi TT 2 + di desa Pasar Keong kecamatan Cibadak Tahun 2015.

Hasil Penelitian menunjukkan bahwa ibu hamil yang berpengetahuan kurang tentang immunisasi TT 2+ proporsinya lebih besar ditemukan pada ibu usia $\leq 30$ tahun $(72,3 \% \%)$ dibandingkan dengan ibu yang berusia > 30 tahun $(37,5 \%)$

Hasil uji statistik diperoleh nilai p.value 0.09 lebih besar dari $\alpha 0.05$ artinya tidak ada hubungan bermakna antara usia ibu dengan pengetahuan tentang immunisasi TT $2+$

2. Hubungan tingkat pendidikan dengan pengetahuan tentang immunisasi TT 2 + pada ibu hamil di desa Pasar Keong kecamatan Cibadak tahun 2015

Hasil Penelitian menunjukkan bahwa Ibu hamil dengan pengetahuan kurang tentang immunisasi TT 2+ proporsinya lebih besar pada ibu hamil yang berpendidikan $\leq$ SLTP $\quad(83,5 \%)$ dibandingkan dengan ibu yang berpendidikan > SLTP $(38,1 \%)$

Hasil uji statistik diperoleh nilai p.value 0.00 lebih kecil dari $\alpha 0.05$ artinya ada hubungan bermakna antara pendidikan Ibu dengan pengetahuan tentang immunisasi TT 2+ . Hasil uji chi- square diperoleh nilai OR sebesar 9,4 artinya ibu hamil dengan pendidikan $\leq$ SLTP memiliki peluang sebanyak 9 kali untuk berpengetahuan kurang tentang immunisasi TT 2+ dibandingkan dengan ibu yang berpendidikan > SLTP.

3. Hubungan antara pekerjaan dengan pengetahuan tentang immunisasi TT 2+ pada ibu hamil di desa Pasar Keong kecamatan Cibadak Tahun 2015

Dari hasil penelitian diperoleh Ibu hamil dengan pengetahuan kurang tentang immunisasi TT $2+$ proporsinya lebih besar pada ibu hamil yang tidak bekerja $(73,9 \%)$ dibandingkan dengan ibu yang bekerja $(33,3 \%)$

Hasil uji statistik diperoleh nilai p.value 0.04 lebih kecil dari $\alpha 0.05$ artinya ada hubungan bermakna antara pekerjaan Ibu dengan pengetahuan tentang immunisasi TT 2+ . Hasil uji chisquare diperoleh nilai OR sebesar 5,6 artinya ibu hamil yang tidak bekerja memiliki peluang sebanyak 6 kali untuk berpengetahuan kurang tentang immunisasi TT 2+ dibandingkan dengan ibu yang bekerja.

4. Hubungan antara Paritas dengan pengetahuan tentang immunisasi TT 2+ di desa Pasar Keong kecamatan Cibadak Tahun 2015 
Hasil penelitian menunjukkan bahwa Ibu hamil dengan pengetahuan kurang tentang immunisasi TT 2+ proporsinya lebih besar pada ibu hamil $\leq$ primi $(71,4 \%)$, dibandingkan dengan ibu hamil >1 Multi $(60 \%)$

Hasil uji statistik diperoleh nilai p.value 0,5 lebih besar dari $\alpha 0.05$ artinya tidak ada hubungan bermakna antara paritas dengan pengetahuan tentang immunisasi TT $2+$.

Hasil Penelitian mewnunjukkan bahwa Ibu hamil dengan pengetahuan kurang tentang immunisasi TT 2+ proporsinya lebih besar pada ibu hamil $\leq$ primi $(71,4 \%)$, dibandingkan dengan ibu hamil >1 Multi $(60 \%)$

Hasil uji statistik diperoleh nilai p.value 0,5 lebih besar dari $\alpha 0.05$ artinya tidak ada hubungan bermakna antara paritas dengan pengetahuan tentang immunisasi TT $2+$.

5. Hubungan antara status immunisasi TT dengan pengetahuan tentang immunisasi TT 2+ di desa Pasar Keong kecamatan Cibadak Tahun 2015

Hasil Penelitian menunjukkan bahwa Ibu hamil dengan pengetahuan kurang tentang immunisasi TT 2+ proporsinya lebih besar pada ibu hamil tidak/belum pernah diimunisasi $(77,1$
\%) dibandingkan dengan ibu tidak diimunisasi $(50 \%)$

Hasil uji statistik diperoleh nilai p.value 0.07 lebih besar dari a 0.05 artinya tidak ada hubungan bermakna antara status immunisasi dengan pengetahuan ibu tentang immunisasi TT $2+$.

6. Hubungan antara keterpaparan informasi dengan pengetahuan tentang immunisasi TT 2+ di desa Pasar Keong kecamatan Cibadak kabupaten Lebak Tahun 2015.

\section{Hasil Penelitian menunjukkan} bahwa Ibu hamil dengan pengetahuan kurang tentang immunisasi TT 2+ proporsinya lebih besar pada ibu hamil yang tidak/belum pernah mendapatkan informasi tentang immunisasi TT $\quad(87,9$ $\%$ dibandingkan dengan ibu yang pernah $(36,4 \% \%)$

Hasil uji statistik diperoleh nilai p.value 0.00 lebih kecil dari $\alpha 0.05$ artinya ada hubungan bermakna antara keterpaparan informasi dengan pengetahuan ibu tentang immunisasi TT 2+. Hasil analisis lanjut diperoleh OR 12,6 \% artinya Ibu-ibu yang tidak pernah terpapar informasi tentang TT 2+ berisiko 13 kali untuk berpengetahuan kurang tentang immunisasi TT 2+ dibandingkan 
dengan ibu-ibu yang pernah terpapar informasi

\section{Pembahasan}

Hasil penelitian menunjukkan bahwa sebagian besar ibu hamil berpengetahuan kurang tentang immunisasi TT $2+(67,3 \%$.). Pengetahuan merupakan hasil dari tahu dan ini terjadi setelah orang melakukan pengindraan terhadap objek tertentu. Pengindraan terjadi melalui pancaindra manusia yakni indra penglihatan, pendengaran, penciuman, rasa dan raba. Sebagian besar pengetahuan manusia diperoleh melalui indra penglihatan dan pendengaran. Pengetahuan (kognitif) merupakan domain yang sangat penting dalam menentukan tindakan seseorang. Tindakan yang didasari oleh pengetahuan akan mempengaruhi perilaku individu (Noto Atmojo 2005).

Hasil penelitian yang dilakukan oleh Mislianti dkk (2012) menggambarkan Derajat nilai keeratan dari hubungan dapat dilihat dari nilai OR 2.497 (CI 95\% 1.394-4.473) artinya responden dengan pengetahuan rendah mempunyai resiko 2,497 kali lebih besar tidak melakukan imunisasi TT jika dibandingkan dengan responden yang berpengetahuan tinggi.

Pengetahuan yang rendah/kurang merupakan salah satu faktor penyebab responden tidak melakukan immunisasi TT. Untuk lebih jelasnya faktor-faktor yang berhubungan dengan pengetahuan ibu hamil tentanng TT 2+ dapat diuraikan berikut;

1. Hubungan usia ibu dengan pengetahuan tentang immunisasi TT 2 + di desa Pasar Keong kecamatan Cibadak Tahun 2015

Hasil penelitian menunjukkan bahwa, sebagian besar Ibu hamil berusia $\leq 30$ tahun $(85,5 \%)$. ibu hamil yang berpengetahuan kurang tentang immunisasi TT $2+$ proporsinya lebih besar ditemukan pada ibu usia $\leq 30$ tahun $(72,3 \% \%)$ dibandingkan dengan ibu yang berusia > 30 tahun (37,5\%). Hasil uji statistik diperoleh nilai p.value 0.09 lebih besar dari $\alpha 0.05$ artinya tidak ada hubungan bermakna antara usia ibu dengan pengetahuan tentang immunisasi TT $2+$.

Bila dilihat dari proporsi ibu yang berpengetahuan kurang tentang immunisasi TT 2+ lebih besar pada ibu yang berusia $\leq 30$ tahun dibandingkan dengan ibu > 30 tahun. .Hal ini sependapat dengan pendapat ahli yaitu Hurlock (2005) dalam bukunya menyatakan semakin cukup umur dan kekuatan seseorang tingkat kematangan dan kekuatan seseorang akan lebih matang dalam berpikir dan bekerja. Dari segi kepercayaan masyarakat seseorang 
akan lebih dewasa akan lebih dipercaya dari orang yang belum cukup tingkat kedewasaannya. Hal ini sebagai akibat dari pengalaman dan kematangan jiwanya.

Pada penelitian ini setelah diuji lebih lanjut ternyata tidak menunjukkan hubungan yang bermakna. Hal ini dimungkinkan karena umur bukanlah merupakan faktor yang dominan, namun masih dipengaruhi oleh faktor-faktor lain misalnya pendidikan ibu. Sekalipun dari sisi umur cukup tingkat kematangannya, tetapi dari sisi pendidikan kurang, akhirnya berdampak terhadap kurangnya pengetahuan Ibu.

2. Hubungan tingkat pendidikan dengan pengetahuan tentang immunisasi TT 2 + pada ibu hamil di desa Pasar Keong kecamatan Cibadak kabupaten Lebak tahun 2015

Hasil penelitian menunjukkan bahwa lebih dari separuh Ibu hamil berpendidikan $\leq$ SLTP $(61,8 \%)$. Hasil analisis lanjut diketahui bahwa, Ibu hamil dengan pengetahuan kurang tentang immunisasi TT 2+ proporsinya lebih besar pada ibu hamil yang berpendidikan $\leq$ SLTP $\quad(83,5 \%)$ dibandingkan dengan ibu yang berpendidikan > SLTP $(38,1 \%)$ Hasil uji statistik diperoleh nilai p.value 0.00 lebih kecil dari $\alpha 0.05$ artinya ada hubungan bermakna antara pendidikan Ibu dengan pengetahuan tentang immunisasi TT $2+$. Hasil uji chi-square diperoleh nilai OR sebesar 9,4 artinya ibu hamil dengan pendidikan $\leq$ SLTP memiliki peluang sebanyak 9 kali untuk berpengetahuan kurang tentang immunisasi TT $2+$ dibandingkan dengan ibu yang berpendidikan > SLTP.

Hasil ini sejalan dengan hasil penelitian (Erma Prihastini DKK, tahun 2014) Berdasarkan hasil perhitungan, diperoleh hasil X2hitung sebesar 25,031, p value sebesar 0,000 dan nilai koefisien kontingensi sebesar 0,543. Hal ini berarti ada hubungan pendidikan ibu hamil dengan pengetahuan imunisasi Tetanus Toksoid (TT)..

Pendidikan yang rendah akan mempengaruhi kemampuan seseorang dalam menerima informasi kesehatan dan pemahaman tentang kesehatan sehingga akan berpengaruh terhadap sikap seseorang dalam melakukan tindakan kesehatan, hal ini sesuai pendapat Notoatmodjo (2005) yang mengatakan tingkat pengetahuan akan mempengaruhi tingkat penguasaan responden terhadap derajat kesehatannya, kerena dalam pendidikan terjadi proses pembelajaran yang selanjutnya akan mempengaruhi perilaku seseorang dalam melakukan tindakan pemeliharaan dan peningkatan kesehatan. Semakin tinggi tingkat 
pendidikan seseorang, semakin mudah menerima informasi sehingga banyak pula pengetahuan yang dimiliknya (Nursalam dan Pariana, 2004).

\section{Hubungan antara pekerjaan dengan} pengetahuan tentang immunisasi TT 2+ pada ibu hamil di desa Pasar Keong kecamatan Cibadak Tahun 2015

Hasil penelitian menggambarkan bahwa sebagian besar Ibu hamil tidak bekerja $(83,6 \%)$. Hasil analisis lanjut diketahui, bahwa Ibu hamil dengan pengetahuan kurang tentang immunisasi TT 2+ proporsinya lebih besar pada ibu hamil yang tidak bekerja $(73,9 \%)$ dibandingkan dengan ibu yang bekerja $(33,3 \%)$. Hasil uji statistik diperoleh nilai p.value 0.04 lebih kecil dari $\alpha 0.05$ artinya ada hubungan bermakna antara pekerjaan dengan pengetahuan ibu hamil tentang immunisasi TT 2+. Hasil uji chi-square diperoleh nilai OR sebesar 6 artinya ibu hamil yang tidak bekerja memiliki peluang sebanyak 6 kali untuk berpengetahuan kurang tentang immunisasi TT 2+ dibandingkan dengan ibu yang bekerja.

Hasil ini sejalan dengan hasil penelitian Erma Prihastanti, dkk (2014) Berdasarkan hasil perhitungan $\mathrm{x} 2$ hitung sebesar 8,085a dan p value 0,018 yang berarti $\mathrm{p}$ value $<\alpha 0,05$. Hal ini berarti secara statistik terdapat hubungan pekerjaan ibu hamil dengan pengetahuan tentang imunisasi Tetanus Toksoid (TT)

Pada penelitian ini setelah diuji lebih lanjut ternyata tidak menunjukkan hubungan yang bermakna.Ibu tidak bekerja kurang mendapat informasi karena ibu hanya di rumah saja dan tidak dapat berkumpul dengan orang lain untuk berdiskusi masalah kesehatan tentang imunisasi TT. Ibu yang bekerja akan bertemu dengan orang lain sehingga dapat berdiskusi tentang kesehatan dan dapat memperoleh informasi kesehatan. Ibu yang bekerja akan memperoleh pengalaman dan pengetahuan baik secara langsung maupun tidak langsung, hal ini sesuai dengan pendapat Mubarak (2009) yang mengatakan lingkungan pekerjaan dapat menjadikan seseorang memperoleh pengalaman dan pengetahuan baik secara langsung maupun tidak langsung.

4. Hubungan antara Paritas dengan pengetahuan tentang immunisasi TT 2+ di desa Pasar Keong kecamatan Cibadak Tahun 2015

Hasil penelitian menunjukkan bahwa Ibu hamil dengan pengetahuan kurang tentang immunisasi TT 2+ proporsinya lebih besar pada ibu hamil $\leq$ primi $(71,4 \%)$, dibandingkan dengan ibu hamil >1 Multi (60\%) Hasil uji statistik diperoleh nilai p.value 0,5 lebih besar 
dari $\alpha 0.05$ artinya tidak ada hubungan bermakna antara paritas dengan pengetahuan tentang immunisasi TT $2+$.

Hasil penelitian ini menunjukkan bahwa proporsi ibu yang berpengetahuan kurang tentang immunisai TT $2+$ lebih banyak ditemukan pada ibu yang baru meliliki anak $\leq 1$ (primi), karena memang pada usia ini ibu belum memiliki pengalaman yang cukup dibandingkan dengan Multi (anak lebih dari satu).

Menurut para ahli paritas ibu mempengaruhi pengetahuan dikarenakan ibu yang telah memiliki beberapa orang anak, akan lebih punya pengalaman dibandingkan dengan ibu yang belum/baru memiliki satu orang anak (Nanda 2013). Pengalamam yang di dapat akan menambah pengetahuan dan wawasan ibu. Menurut Sarjono (2004), pengalaman merupakan faktor yang mempunyai peran dan tidak kalah pentingnya dengan pendidikan, karena pengalaman merupakan guru paling berharga menentukan tingkat pengetahuan seseorang, namun setelah diuji lebih lanjut hubungan ini tidak bermakna.

5. Hubungan antara status immunisasi TT dengan pengetahuan tentang immunisasi TT 2+ di desa Pasar Keong kecamatan Cibadak kabupaten Lebak Tahun 2015
Hasil analisis menunjukkan bahwa lebih dari separuh $(63,6 \%)$ Ibu hamil di desa Pasar Keong belum melaksanakan Immunisasi TT. Hasil analisis lanjut diketahui bahwa Ibu hamil dengan pengetahuan kurang tentang immunisasi TT $2+$ proporsinya lebih besar pada ibu hamil yang tidak/belum pernah diimunisasi (77,1 \%) dibandingkan dengan ibu tidak diimunisasi (50\%) Hasil uji statistik diperoleh nilai p.value 0.07 lebih besar dari $\alpha 0.05$ artinya tidak ada hubungan bermakna antara status immunisasi dengan pengetahuan ibu tentang immunisasi TT $2+$.

Hasil penelitian ini tidak sejalan dengan Hasil penelitian terdahulu menunjukkan bahwa ada hubungan bermakna antara pengetahuan dengan pemberian immunisasi TT, diperoleh nilai OR 2,497 artinya responden dengan prengetahuan rendah memiliki risiko 2 kali lebih besar tidak melakukan immunisasi dibandingkan dengan responden berpengetahuan tinggi (Mislianti, 2012). Hal ini dimungkinkan karena ibu hamil yang tidak diimmunisasi jumlahnya cukup besar, dan immunisasi yang dipantau baru terbatas pada immunisasi TT yang diberikan baru 1 kali2 kali, namun bila dilihat dari proporsi ibu 
yang berpengetahuan kurang lebih banyak ditemukan pada ibu yang tidak diimunisai, dan dilihat dari tingkat kemaknaan tidak jauh berbeda dengan hasil penelitian sebelumnya.

6. Hubungan antara keterpaparan informasi dengan pengetahuan tentang immunisasi TT 2+ di desa Pasar Keong kecamatan Cibadak Tahun 2015

Hasil penelitian menggambarkan bahwa, sebagian basar Ibu hamil (60\%) tidak terpapar informasi tentang immunisasi TT $2+$. Hasil penelitian menunjukkan bahwa, Ibu hamil dengan pengetahuan kurang tentang immunisasi TT 2+ proporsinya lebih besar pada ibu hamil yang tidak/belum pernah mendapatkan informasi tentang immunisasi TT (87,9\%) dibandingkan dengan ibu yang pernah $(36,4 \% \%)$

Hasil uji statistik diperoleh nilai p.value 0.00 lebih kecil dari $\alpha 0.05$ artinya ada hubungan bermakna antara keterpaparan informasi dengan pengetahuan ibu tentang immunisasi TT 2+. Hasil analisis lanjut diperoleh OR 12,6 $\%$ artinya Ibu-ibu yang tidak pernah terpapar informasi tentang TT $2+$ berisiko 13 kali untuk berpengetahuan kurang tentang immunisasi TT 2+ dibandingkan dengan ibu-ibu yang pernah terpapar informasi.
Informasi adalah sesuatu yang dapat diketahui. Informasi dijumpai dalam kehidupan sehari-hari, yang diperoleh dari data dan observasi terhadap dunia sekitar serta diteruskan melalui komunikasi. Ideal nya semakin sering seseorang mendapatkan informasi, maka pengetahuan akan bertambah dan semakin baik. Pada penelitian ini menggambarkan bahwa keterpaparan informasi kesehatan secara umum sering dilakukan oleh puskesmas setempat, namun terkait Immunisasi TT $2+$ masih perlu ditingkatkan, mengingat masih ditemukan $60 \%$ ibu hamil yang belum terpapar informasi tentang TT 2+.dan bila dilihat dari faktor risiko bahwa ibu hamil yang tidak terpapar informasi tentang TT $2+$ berisikon untuk berpengetahuan kurang tentang immunisai TT, yang akhirnya berdampak terhadap rendahnya cakupan immunisai TT.

\section{Simpulan}

Dari hasil pengolahan dan analisa data tentang hubungan karateristik ibu dengan pengetahuan ibu hamil tentang TT 2+ di desa Pasar Keong kecamatan Cibadak kabupaten Lebak dapat disimpulkan sebagai berikut;

1. Sebagian besar ibu hamil berpengetahuan kurang tentang immunisasi TT $2+(67,3 \%)$ 
2. Sebagian besar ibu hamil berusia $\leq$ 30 tahun $(85,5 \%)$

3. Lebih dari separuh ibu hamil berpendidikan SLTP kebawah $(61,8 \%)$

4. Sebagian besar ibu hamil tidak bekerja $(83,6 \%)$

5. Lebih dari separuh ibu hamil memiliki anak $\leq 1(63,6 \%)$

6. Lebih dari separuhnya ibu hamil tidak/belum mendapatkan TT $(63,6 \%)$

7. Lebih dari separuh ibu hamil tidak/belum terpapar informasi tentang immunisasi TT $2+(60 \%)$

8. Ada hubungan bermakna antara pendidikan ibu, pekerjaan ibu, keterpaparan informasi dengan pengetahuan tentang immunisasi TT $2+$.

9. Tidak ada hubungan bermakna antara usia, paritas, status immunisai TT 2+ dengan pengetahuan tentang immunisasi TT 2+ .

\section{DAFTAR PUSTAKA}

Achmad Feryanto Fadlun, Asuhan Kebidanan Patologis, Salemba Medika 2011

Alimul Hayat A.Aziz, Metode Penelitian Kebidanan dan tehnik analisa data, Salemba medika Jakarta, 2011

Benzion Taber, Kapita Selekta Kedaruratan Obstetri Ginekologi, Penerbit buku kedokteran ECG Jakarta3
Danim Sudarwan Prof. Dr, Darwis.SKP, Metode Penelitian Kebidanan, prosedur, kebijakan dan etik, ECG, Jakarta 2003

http://www.skripsistikes.wordpress.com Istichomah, S.Kep, Ns, dosen Prodi Ilmu Keperawatan Surya Global Yogyakarta

Indriani Nanien, Thesis ; Analisis faktorfaktor yang berhubungan dengan Eklampsia di RSUD Tegal, tahun 2012

Joeharno M. SKM, Analisis data dengan SPSS Belajar Mudah untuk Penelitian Kesehatan, Penerbit Buku Kedokteran ECG, 2013

Marsha Khumaira, Ilmu Kebidanan , Citra Pustaka Jogyakarta, tahun 2012 Norma Nita D.S.SiT, Mustika Dwi S,S.SiT, Asuhan kebidanan Patologi Teori dan tinjauan kasus. Numed, Yogyakarta 2013

Notoatmodjo Soekidjo Prof. Dr, Metodogi Penelitian kesehatan, Rineka Cipta Jakarta tahun 2010.

Prawiroharjo Sarwono, Ilmu Kebidanan edisi 4, PT Bina Pustaka Sarwono Prawiroharjo, Jakarta tahun 2010

Yeyeh Rukiyah Ai , S.SIT.MKM, Lia Yuluianti, Am.Keb.MKM, Asuhan Kebidanan IV ( patrologi kebidanan), Trans info Media Jakarta, 2010 